\title{
Temperature effects on the bridge structure during the all-day monitoring
}

\author{
Ondřej Michal, Rudolf Urban \\ Department of Special Geodesy, Faculty of Civil Engineering \\ Czech Technical University in Prague \\ Thákurova 7, 16629 Prague 6, Czech Republic \\ ondrej.michal@fsv.cvut.cz, rudolf.urban@fsv.cvut.cz
}

\begin{abstract}
In current time the large amount of pre-stressed bridge structures is used. Their horizontal and vertical displacements are well predicted, but for verification of theoretical results is necessary to measure real displacements of these structures depending on external conditions. Given by the complexity of the design and by the inhomogenity of external influences (especially temperature of the atmosphere, insolation, wind speed, etc.) cannot yet be reliably determined the changes of the construction caused by the immediate state of the environment and to distinguish them from irreversible (permanent) deformation of the structure.

In this paper the deflection line of the bridge of general Chábera over river Labe during the all-day monitoring will be analysed. There is dense coverage of stabilized points enabling accurate approximation of the displacement of the bridge structure. The paper is focused especially on temperature effects on the bridge structure. The temperature changes cause the deformation of the construction not immediately, but with the time shift between change of temperature and structure deformation. Although the points are stabilized on both sides of the bridge deck, for the analysis of results were used only the points on the left side of the main span, where the biggest vertical displacements was detected. For testing of dependence of the time shift of the structure deformations and structure temperature the Pearson coefficient of correlation was used.
\end{abstract}

Keywords: Deflection line, Pearson correlation, time shift.

\section{Introduction}

Measurement of vertical displacement of building structures was usually solved by precise leveling, which has sufficient accuracy for significant determine of deformation according the standard ČSN 730405 . This standard is concerned with long-term displacements and the methodic respond that. Nowadays modern total station has almost the same accuracy and the measurement is faster than leveling. On the other hand, spatial polar method is more sensitive on outer conditions, especially atmospheric refraction. Therefore is still used less than leveling [6].

Spatial polar method is used in measurement of vertical and longitudinal deformation of bridges. In [1] was used trigonometric method for the determination of longitudinal deformations with very high (sub-millimeter) accuracy. The determination of the vertical deformation 
from the changes of zenith angle was used in [10], where the influence of refraction was investigated.

The results from [11] and [9] demonstrate that spatial polar method has sufficient accuracy for determining of vertical displacements of bridges respecting correct procedures suppressing the atmospheric refraction.

The measured points can be difficult to access during the measurement of deflection. Therefore new methods with passive reflection are used. Displacements with high frequency can be measured by Ground-Based (GB) radar interferometry. This new technology can be effectively used for measuring of steel bridges with high accuracy, because there is no need to stabilize and signalized the measured points [2]. GB radar interferometry can be used for concrete structures also. In this case the observed points have to be signaled by the corner reflectors. Accuracy of measurement stays still very high [8].

Deformations of complex structures can be measured by laser scanning with advantage. This method provides large amount of data, after the statistical processing can be obtained the displacements of parts of structure. Unfortunately, the accuracy is still worse than in case of the other methods [3].

The aim of this paper is investigating of the vertical displacements in relatively short time. The measurement has to be fast, so the spatial polar method was used. The structure was monitored for 24 hours in 24 epochs. Temperature of the air and the structure was observed during measurement. Linear dependence was expected between temperature changes and displacements with unknown time shift between temperature and structure change. The time of the experiment was chosen carefully, the weather conditions were the same several days before and after the monitoring. Temperature changed continuously during day and night period and the same periodicity was expected in displacements.

\subsection{General Chabera bridge}

The bridge crosses the river Elbe near the town Litoměřice in Czech Republic. The bridge (Figure 1 and Figure 2) is the part of the road II/247 - connection of the industry area Prosmyky to D8 highway. The superstructure is designed as a continuous beam with box girder cross-section. Total length of the structure is $584.5 \mathrm{~m}$. It is divided to 7 spans with lengths $43+64+72+90+151+102+60 \mathrm{~m}-[4]$.

\section{Material and methods}

The Trimble S6 Robotic instrument (standard deviation of the horizontal direction and zenith angle measurement is $\sigma_{\phi}=\sigma_{\zeta}=0.3 \mathrm{mgon}$, standard deviation of the distance measurement is $\sigma_{D}=1 \mathrm{~mm}+1 \mathrm{ppm} \times \mathrm{D}$ ) with a relevant omnidirectional reflection prism was used for the measuring (on Figure 3). S6 is a robotic total station with automatic targeting system. Range pole has special flat heel, which ensures the same height of the target in all epochs. The bridge structure was measured by the space polar method. Automatic targeting on omnidirectional prism was used.

For deflection line time and temperature analysis it was necessary to determine its shape in time during the day. There was monitored 16 points on the left side of the main span during 


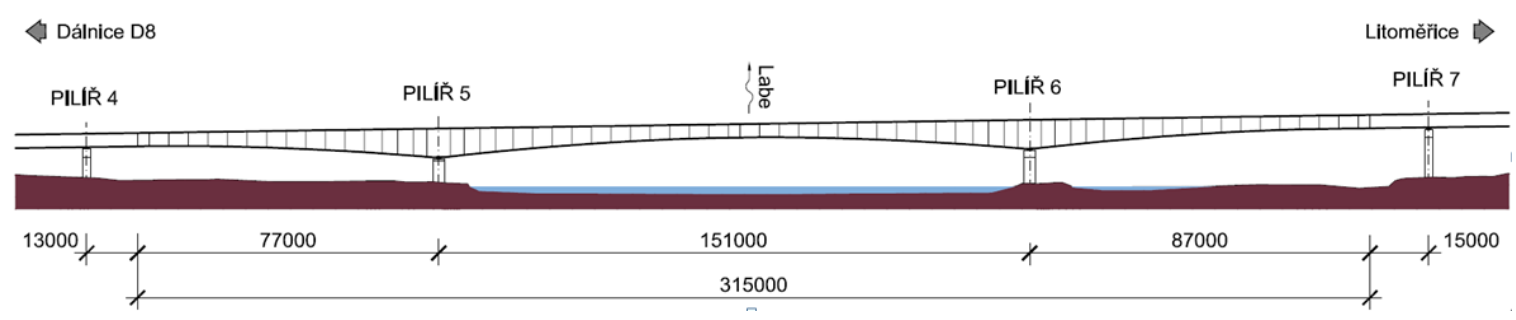

Figure 1: Longitudinal section of superstructure

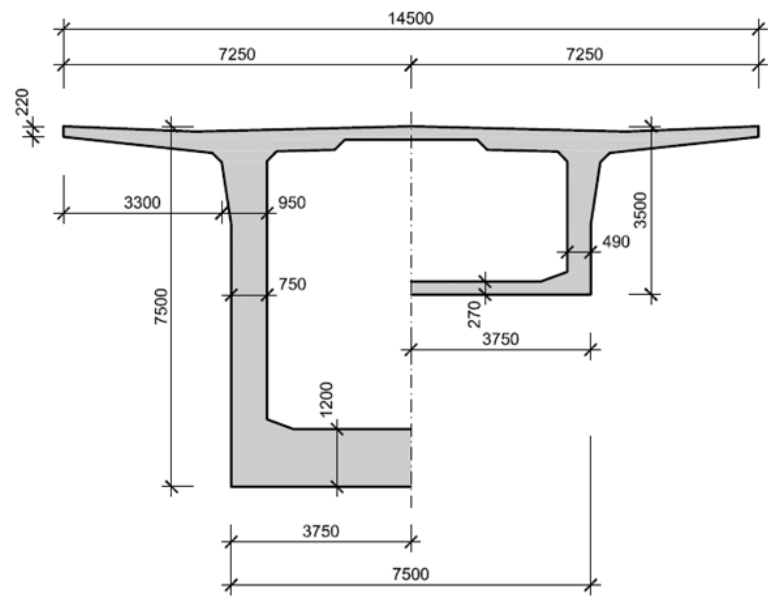

Figure 2: Cross section of superstructure

the period of 24 hours. Points are stabilized by metal leveling nails in bridge structure. The spacing between them is ten meters, it is sufficient for deflection line approximation.

Atmospheric conditions during measurement were extreme and so were the expected vertical changes of the monitored points, it was good for experiment. The difference between maximum and minimum structure temperature was over $20^{\circ} \mathrm{C}$. Weather conditions are summarized in Figure 4.

The deflection line of the main span was measured by spatial polar method. There was one connecting point on the left bank of the river and two control points at the end of the bridge construction - situation during measurement is shown on Figure 5.

The predicted displacements were less than 10 millimeters. The standard deviation of determined vertical point's displacement of $1 \mathrm{~mm}$ was then required, therefore the maximum horizontal distance to observed point was reduced to $80 \mathrm{~m} \mathrm{[7]}$.

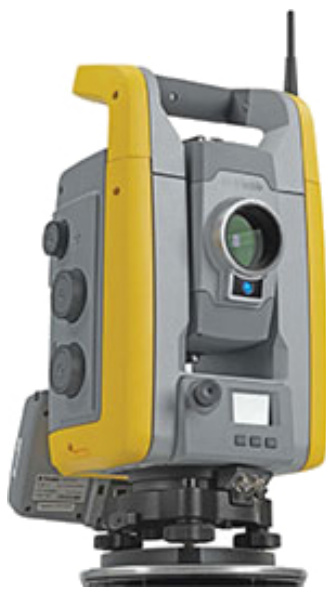

Figure 3: Trimble S6 Robotic

Temperature of the atmosphere at various heights above the bridge was measured to verify of the refraction influence. Measurement of all points took forty minutes, so deflection line was intended in epoch every one hour, whole experiment lasts 24 hour and therefore 24 epochs were 


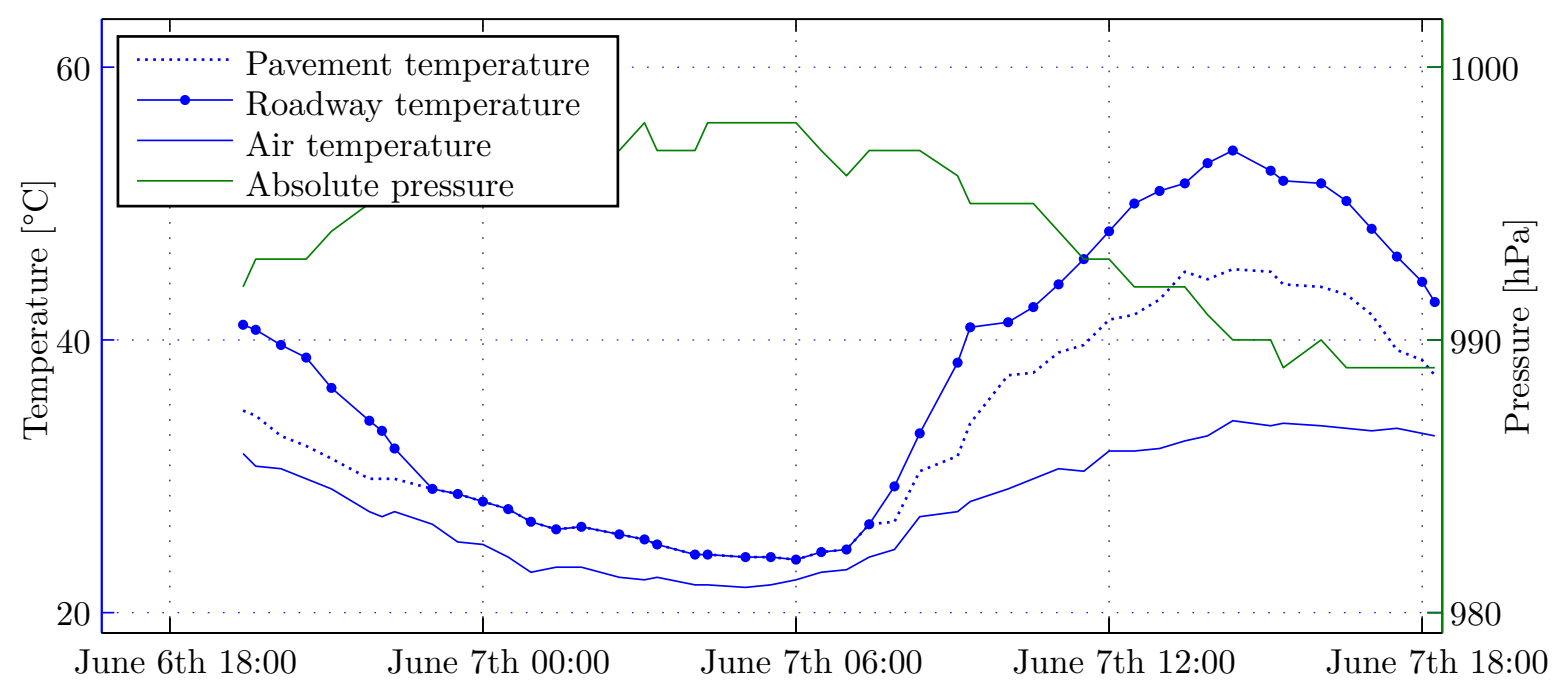

Figure 4: Weather conditions during measurement

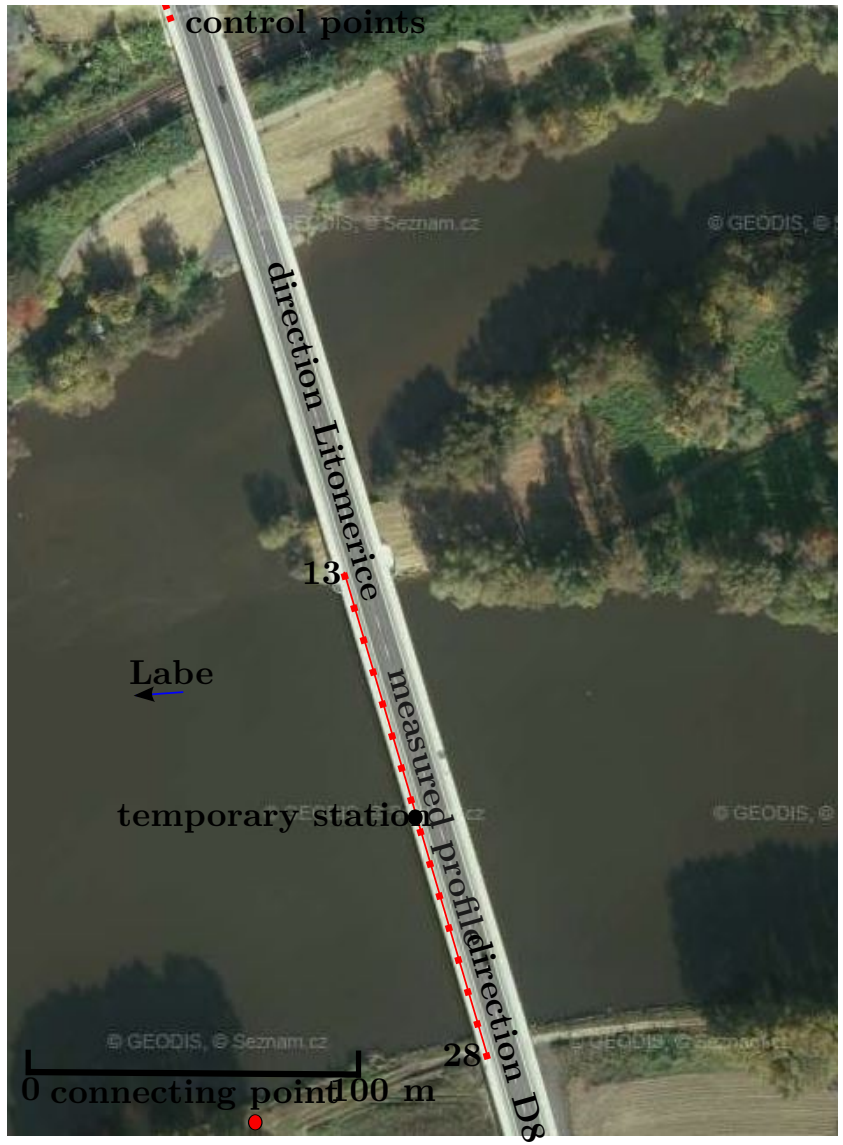

Figure 5: Configuration of measurement (Areal Image @ Geodis) 
measured. First epoch was measured at 19:00, June 6th 2013, last epoch at 18 o'clock next day [5]. The heights of all points were calculated in local vertical datum (correction for Earth curvature was included) using simple trigonometric functions:

$$
h_{i}=h_{p b}+S_{p b} \cos z_{p b}-S_{i} \cos z_{i}
$$

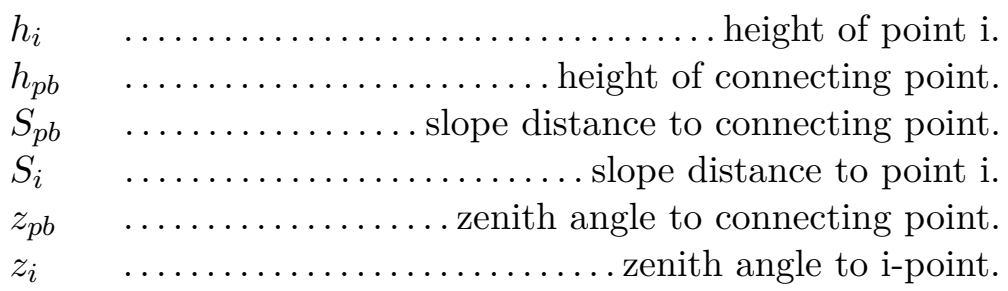

\section{Results}

Vertical displacements reached values up to 10 millimeters maximally on points in the middle of the main span. Presentation of all values from all epochs would be unclear and not very interesting, only one epoch with biggest displacements is presented here for idea about their values - Table 1. In next section the relation between displacements and temperature will be demonstrated.

\subsection{Relation between displacement and temperature in the same time}

First were calculated Pearson correlation coefficients between vertical displacements and temperature of air and structure in the same time. Calculation was applied only on eight points in the middle of main span, where the displacements were the biggest, all over $6 \mathrm{~mm}$. The result, however, was not according to the expectations.

Correlation coefficients of these eight points are close to zero - Table 2, therefore they was not calculated for the remaining points. Very low values of correlation coefficients were caused by unknown time shift between temperature and structure changes. The time shift is visible in Figure 6. Extremes of both quantities are in different time - maximum of displacement is circa 5 hours after minimum of temperature. This time shift will be investigated.

Table 1: The epoch with biggest displacements

\begin{tabular}{|c|c|c|c|c|c|c|c|c|c|c|c|c|c|c|c|c|}
\hline$\sigma_{d}=1.1 \mathrm{~mm}$ & \multicolumn{16}{|c|}{ Point number } \\
\hline Epoch 14 & 13 & 14 & 15 & 16 & 17 & 18 & 19 & 20 & 21 & 22 & 23 & 24 & 25 & 26 & & 28 \\
\hline Displacement [mm] & 2.4 & 2.3 & 3.3 & 4.5 & 5.2 & 6.2 & \begin{tabular}{|c|}
6.7 \\
\end{tabular} & 7.3 & 7.0 & 6.6 & 5.8 & 4.9 & 4.0 & 2.9 & 2.1 & 2.3 \\
\hline
\end{tabular}

Table 2: Correlation coefficients between displacements and temperature

\begin{tabular}{|c|c|c|c|c|c|c|c|c|l|}
\hline Point & $\mathbf{2 4}$ & $\mathbf{2 3}$ & $\mathbf{2 2}$ & $\mathbf{2 1}$ & $\mathbf{2 0}$ & $\mathbf{1 9}$ & $\mathbf{1 8}$ & $\mathbf{1 7}$ & \\
\hline \hline $\begin{array}{l}\text { Correlation } \\
\text { coeficients }\end{array}$ & 0,10 & 0,08 & 0,05 & 0,05 & 0,02 & 0,04 & 0,01 & 0,03 & $\begin{array}{l}\text { With air tem- } \\
\text { perature }\end{array}$ \\
\hline $\begin{array}{l}\text { Correlation } \\
\text { coeficients }\end{array}$ & 0,10 & 0,08 & 0,05 & 0,05 & 0,02 & 0,04 & 0,01 & 0,03 & $\begin{array}{l}\text { With structure } \\
\text { tempertature }\end{array}$ \\
\hline
\end{tabular}

Geoinformatics FCE CTU 14(1), 2015 


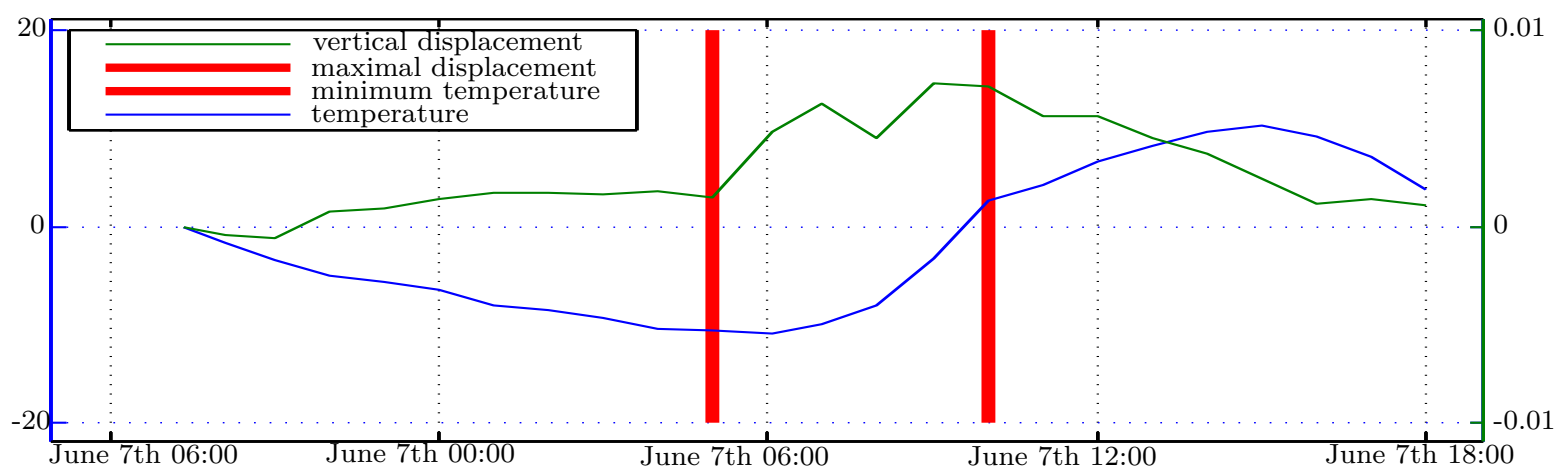

Figure 6: Time shift between displacements and temperature changes

a)

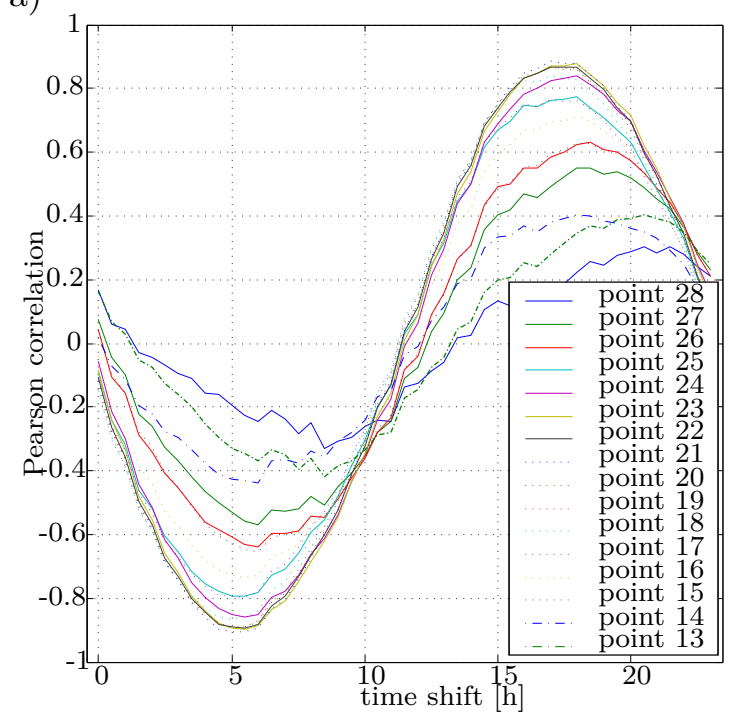

b)

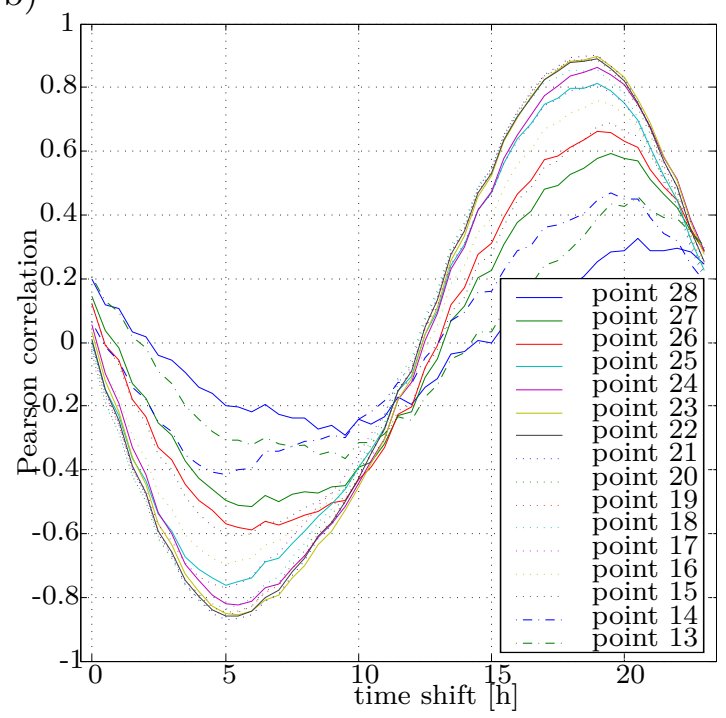

Figure 7: Time shift between displacements and a) air temperature changes b) structure temperature changes

\subsection{Time shift between temperature and vertical displacement}

Correlation function (from correlation coefficients) was used for determination of time shift between temperature changes and displacements of structure. The displacements were measured every hour, while the temperature was monitored almost continually. Correlation coefficient was calculated with time shift from 0 to 24 hour with step 0.5 hour. The course of correlation function depending on the time shift was obtained.

For both air temperature and structure temperature were correlation functions calculated. Graphs of functions were presented in Figure 7. These graphs are point symmetric and seem to be periodical, which corresponds to the assumptions.

The same functions are presented in Figure 8 in 3D graph. Here we can see that extremes of correlation function are greater in the middle of the main span, where displacements were greater, too. 


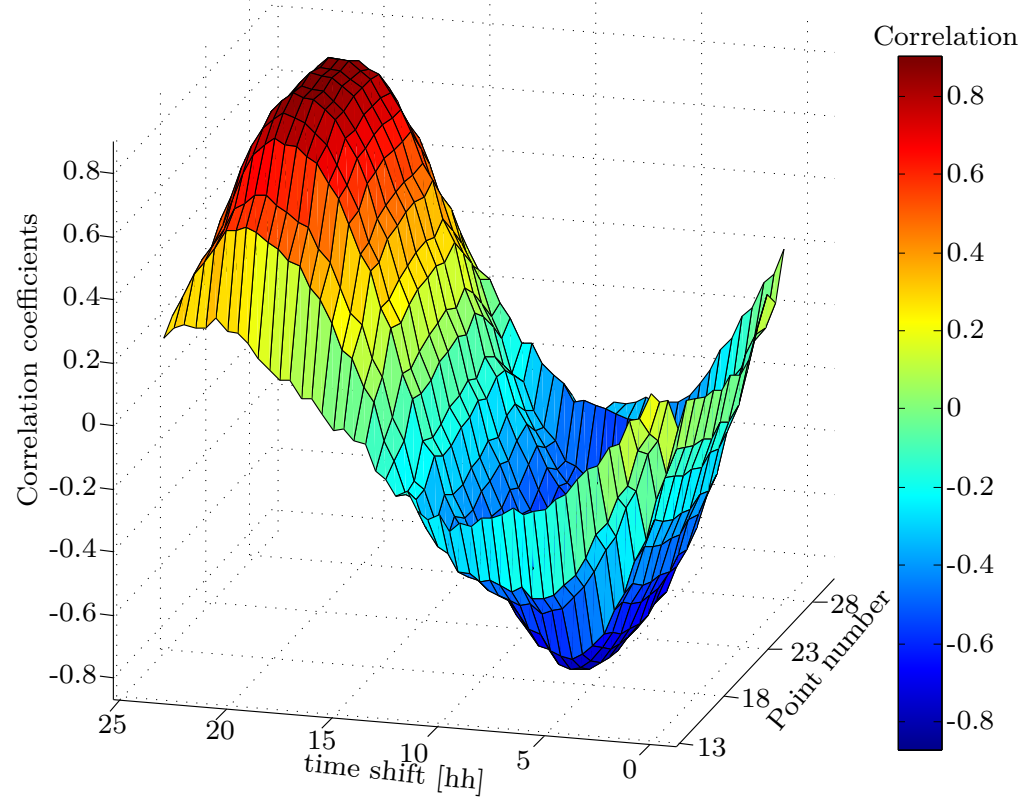

Figure 8: Time shift between displacements and temperature changes in 3D figure

Assuming, that correlation function is a period function with the period one day long we get two extremes of correlation function. If we compute exact time of both extremes, we get time shift and its supplement to one period. That gives us 2 values of time shift for each point.

Values of correlation function in its extremes were compared with critical value of Pearson correlation coefficient - (2).

$$
r_{k}=\left(\frac{F_{k}}{n-2-F_{k}}\right)^{\frac{1}{2}}
$$

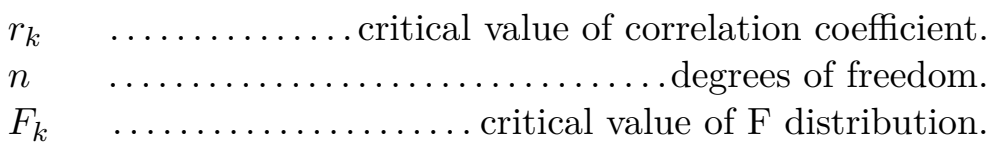

For $n=24$ (24 epochs of measurement) is $r_{k}=0,413$.

If the value of correlation function was lower than its critical value, time shift from this point was not used for next computations. Correlation coefficient was significant at all points except point 28 , which is situated above the support and its displacement was very small.

In Table 3 are values of extremes of correlation function and appropriate time shift for relation with temperature of air and structure both. There are both extremes of correlation functions and appropriate time shift. The time shift from minimum of correlation function fluctuate around five hours and the time shift from maximum of correlation function around 19 hours, which is supplement to 24 hours.

The time shift from all points is very consistent. Its values fluctuate between 5 and 6 hours. Only on point 13 the time shift is 8 and a half hour. But point 13 is situated identically like point 28 above the support and maximum of correlation function only slightly outperforms the critical value. 
Table 3: Determining of time shift between temperature and structure deflections

\begin{tabular}{|c|c|c|c|c|c|c|c|c|c|c|c|c|c|c|c|c|c|c|}
\hline \multicolumn{2}{|c|}{$\begin{array}{c}\text { Point } \\
\text { number }\end{array}$} & 28 & 27 & 26 & 25 & 24 & 23 & 22 & 21 & 20 & 19 & 18 & 17 & 16 & 15 & 14 & 13 & $\begin{array}{l}\text { Average } \\
\text { shift [h] }\end{array}$ \\
\hline & $\mathrm{r}$ & 0.30 & 0.55 & 0.63 & 0.77 & 0.84 & 0.88 & 0.87 & 0.88 & 0.87 & 0.87 & 0.84 & 0.77 & 0.71 & 0.63 & 0.40 & 0.40 & 5.4 \\
\hline & $\mathrm{r}$ & .33 & -0.57 & -0.64 & -0.79 & -0.86 & -0.90 & -0.89 & -0.91 & -0.89 & -0.89 & -0.87 & -0.80 & -0.74 & -0.66 & -0.44 & -0.4 & \\
\hline & Shift [h] & & 18.5 & 18.5 & 18.0 & 18.0 & 18.0 & 17.0 & 17.0 & 17.0 & 17.0 & 17.0 & 17.0 & 18.0 & 18.0 & & & \multirow{2}{*}{5.5} \\
\hline & Shift [h] & & 6.0 & 6.0 & 5.0 & 5.5 & 5.5 & 5.5 & 5.5 & 5.0 & 5.5 & 5.0 & 5.5 & 5.5 & 6.0 & 6.0 & 8.5 & \\
\hline \multirow{4}{*}{ 莍 } & $\mathrm{r}$ & 0.33 & 0.59 & 0.66 & 0.81 & 0.86 & 0.90 & 0.89 & 0.90 & 0.89 & 0.89 & 0.86 & 0.81 & 0.76 & 0.69 & 0.47 & 0.46 & 4.9 \\
\hline & $\mathrm{r}$ & -0.29 & -0.51 & -0.59 & -0.76 & -0.82 & -0.86 & -0.86 & -0.87 & -0.86 & -0.85 & -0.84 & -0.77 & -0.70 & -0.61 & -0.42 & -0.37 & \\
\hline & Shift [h] & & 19.5 & 19.0 & 19.0 & 19.0 & 19.0 & 19.0 & 19.0 & 19.0 & 19.0 & 19.0 & 19.0 & 19.0 & 19.5 & 19.5 & 20.5 & \multirow[b]{2}{*}{5.9} \\
\hline & Shift [h] & & 6.0 & 6.0 & 5.0 & 5.5 & 5.5 & 5.0 & 5.0 & 5.0 & 5.0 & 5.0 & 5.0 & 5.0 & 5.5 & 5.0 & & \\
\hline
\end{tabular}

Resultant time shift was calculated as a weighted average. The values of extremes of correlation functions were used as weight. The time shift between displacements of structure and their cause is five hours.

\section{Conclusion}

The direct correlation was found between vertical displacements and changes of both the air and structure temperature using Pearson correlation coefficient.

It was found that structure reacts to temperature changes with quite a delay. This time shift was calculated using course of the correlation function. Its values significantly outperform the critical value and are close to 1, which indicates functional dependency.

This time shift depends on the thermal transmittance of the structure and temperature difference and is not generally valid. It is necessary to consider the effect of this delay during precise measurement of bridges with large span like load tests. It may cause major inaccuracies and completely invalidate otherwise properly conducted measurement.

\section{Acknowledgement}

The article was written with support of the internal grants of Czech Technical University in Prague SGS15 "Optimization of acquisition and processing of 3D data for purpose of engineering surveying"

\section{References}

[1] Jaroslav Braun and Martin Štroner. "Geodetic Measurement of Longitudinal Displacements of the Railway Bridge". In: Geoinformatics FCE CTU 12 (June 2014), pp. 16-21. DOI: $10.14311 /$ gi.12.3.

[2] Ján Erdélyi et al. "Monitoring of a concrete roof using terrestrial laser scanning". In: Geoinformatics FCE CTU 13 (Dec. 2014), pp. 25-30. DOI: 10.14311/gi.13.3.

[3] Ján Erdélyi et al. "Určovanie posunov a pretvorení železobetónových konštrukcií pomocou TLS". In: Geodézia, kartografia a geografické informačné systémy. Košice: Technical University, BERG Faculty, 2012. ISBN: 978-80-553-1173-9. 
[4] Václav Kvasnička. "Bridge over Elbe river in Litoměřice". In: Structural concrete in the Czech Republic 2006-2009: national report of the Czech Republic : 3rd fib Congress Washington. Prague: Czech Concrete Society, c2010, pp. 34-37. ISBN: 978-80-903806-0-8. URL: http://www.metrostav.cz/pdf/reference/CBS_NZ2010_06_PRINT.pdf.

[5] Ondřej Michal. "Analysis of deflection of the bridge construction". Master thesis. Czech Technical University in Prague, 2015. URL: http://geo.fsv.cvut.cz/proj/dp/2015/ ondrej-michal-dp-2015.pdf.

[6] Ondřej Michal and Rudolf Urban. "Analýza technologie pro určování průhybové čáry mostních konstrukcí". In: Grant Journal 2.2 (2013). ISSN: 1805-062X. URL: http:// www grantjournal.com/issue/0201/PDF/0201urban.pdf.

[7] Martin Štroner and Miroslav Hampacher. Zpracování a analýza měření v inženýrské geodézii. Praha: CTU Publishing House, 2011, p. 313. ISBN: 978-80-01-04900-6.

[8] Milan Talich. "Přesné monitorování svislých průhybů mostních konstrukcí metodou pozemní radarové interferometrie". In: XII. mezinárodní konference Geodézie a kartografie v dopravě, Olomouc 4.-5.9. 2014. Český svaz geodetů a kartografů, 2014, pp. 7588. ISBN: 978-80-02-02553-5.

[9] Rudolf Urban and Martin Štroner. "Measurement of deflection line on bridges". In: Reports on Geodesy and Geoinformatics 95.1 (Jan. 2013). DOI: 10.2478/rgg-20130013.

[10] Rudolf Urban, Martin Štroner, and Václav Jurga. "Development of Bridge Deflections in the 24-hours Cycle". In: INGEO 2014. Vol. 1. České vysoké učení technické v Praze, 2014, pp. 155-160. ISBN: 978-80-01-05469-7.

[11] Lukáš Vráblík, Martin Štroner, and Rudolf Urban. "Measurement of bridge body across the river Labe in Melnik". In: Acta Montanistica Slovaca (2009), pp. 79-85. ISSN: 13351788 . 